\title{
Accessibility of Brzozów by public transport on a local, regional and national scale
}

\author{
Łukasz Fiedeń \\ Jagiellonian University, Institute of Geography and Spatial Management, Department of Regional Development, ul. Gronostajowa 7, 30-387 Krakow \\ lukasz.fieden@doctoral.uj.edu.pl
}

\begin{abstract}
Major changes can be observed in the way that the public transport system in Poland operates as a result of the structural and ownership transformations of the former state-owned Motor Transport Company (Przedsiębiorstwo Komunikacji Samochodowej [PKS]). An analysis was carried out of the town's existing public transport connections in order to determine the impact of these changes on the mobility of the residents of a small town. The town of Brzozów was selected for the research. After August 2013, PKS Krosno S.A. withdrew from the provision of services on many bus routes in that area.

The external accessibility of public transport in Brzozów was presented at three scales: local, intra-regional and national. Each of these has its own characteristics, and the bus routes provided on each of these scales have different significance for the inhabitants and the functioning of the economy.

Accessibility by public transport in Brzozów is very good and strongly correlated with the city's functional links on local, regional and national scales. The main transport axis of the city is the route connecting Rzeszów (the capital of Podkarpackie Province) with the Bieszczady Mountains (an area of great value for tourism).

On the local market, the desire to adapt the carriers' provision to the needs of students and the employees of large companies, while providing for university students on the market for long-distance transport, provided the main motivations for changes in the public transport system in the area of Brzozów Municipality.
\end{abstract}

Keywords: accessibility, Brzozów, public transport

submitted: May 2017

reviewed: July 2017

accepted: August 2017

\section{Introduction}

Access to all kinds of goods and services is very important in daily life. Sometimes it determines human health or even life itself. However, one should keep in mind that different types of resources are not distributed equally. As a result, people must move to acquire them, so it can be concluded that the possibility of moving in geographical space directly affects human life and that the accessibility of transport may be one of the determinants of living standards.

The term "accessibility" is frequently used. However, researchers understand this concept differently, and thus it is difficult to indicate one definition that will take into account all aspects of this concept (Taylor 1999, Moseley 1979). Nevertheless, it seems that the most significant fact is that when talking about accessibility, geographers emphasise the necessity (ability/inability) to travel certain distances in space (Ratajczak 1992). A two-part definition of accessibility is applied by Z. Taylor (1997: 261). The first part describes accessibility as a "chance or opportunity that enables one to take advantage of different types of activities". In the second part of the definition, the author emphasises that the subject of accessibility is a person who permanently inhabits a given area. It seems that the issue of permanent or temporary residence in a certain area is not crucial, but referring accessibility to a human being presents the most important - human - aspect of the problem. The fact that accessibility is determined by location is mentioned more frequently (Guzik 2003) which ignores the key role of human beings in the use of goods and services.

The term "transport accessibility" is explained by K. Warakomska (1992: 68), who states that transport accessibility is the "ability to reach a given point from a place of permanent or temporary residence, usually by means of transport”. J. Black and M. Conroy (1977) understand spatial accessibility as the ease with which a given activity can be reached (at a specific location) from a certain location by using means of transport. R. Guzik (2003) underlines that accessibility should not be considered equivalent to reachability. Accessibility does not mean the actual use of the service, but only the possibility of using it, which is not obligatory. Thus, while accessibility should be linked with space, reachability is more associated with financial or social issues.

In this paper, the author will focus on analysing the functioning of the public transport system in Brzozów on three scales: local, regional and national. The analysis will provide answers to the following questions:

- What is the external accessibility of public transport in Brzozów?

- What changes are happening in the public transport system in the Brzozów region? 
- What should be changed to make the public transport system in Brzozów operate better?

The definition of public transport is well known. According to the Cambridge Dictionary, it is a "system of vehicles such as buses and trains that operate at regular times on fixed routes and are used by the public". This definition fully complies with Polish legislation, so it can be used for the purpose of research in Polish conditions. The direct reason for conducting the research was provided by the events accompanying the privatisation of PKS Krosno S.A., the major carrier on the local market. After these changes of ownership and function (August 2013) within the area of the company's operation, many individual bus runs were withdrawn and many regular lines were removed. The gap that occurred is currently being filled by services provided by smaller, private carriers. Detailed research was conducted about one and a half years after the changes. Its main purpose was to prepare a precise assessment of the existing public transport provision while at the same time attempting to identify the main causes of changes in the system in question.

\section{Study area}

Brzozów lies in Brzozów Municipality in Brzozów District, Podkarpackie Province in south-eastern Poland (Figures 1-2). The town covers an area of $11 \mathrm{~km}^{2}$ and has 7509 inhabitants ${ }^{1}$. The inhabitants of Brzozów constitute $28.2 \%$ of the population of the municipality with a population density of 683 persons $/ \mathrm{km}^{2}$.

There are no national roads running through the area of the commune, but there are three provincial roads: Nos. 835, 886 and 887. It should be mentioned that the eastern ring road of Brzozów was opened on $19^{\text {th }}$ Nov. 2015 as a part of provincial road 886 . As a result of this event, the alignment

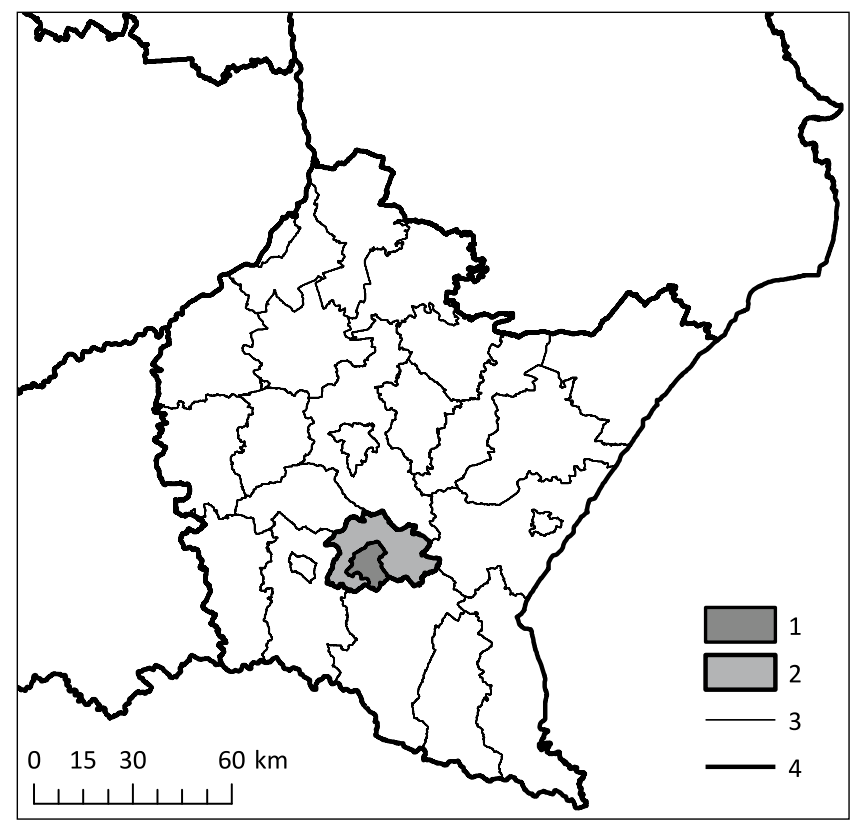

Figure 1. Administrative location of Brzozów Commune

Explanations: 1 - Brzozów municipality, 2 - Brzozów District, 3 - district boundaries, 4 - province boundaries

Source: author's own research.

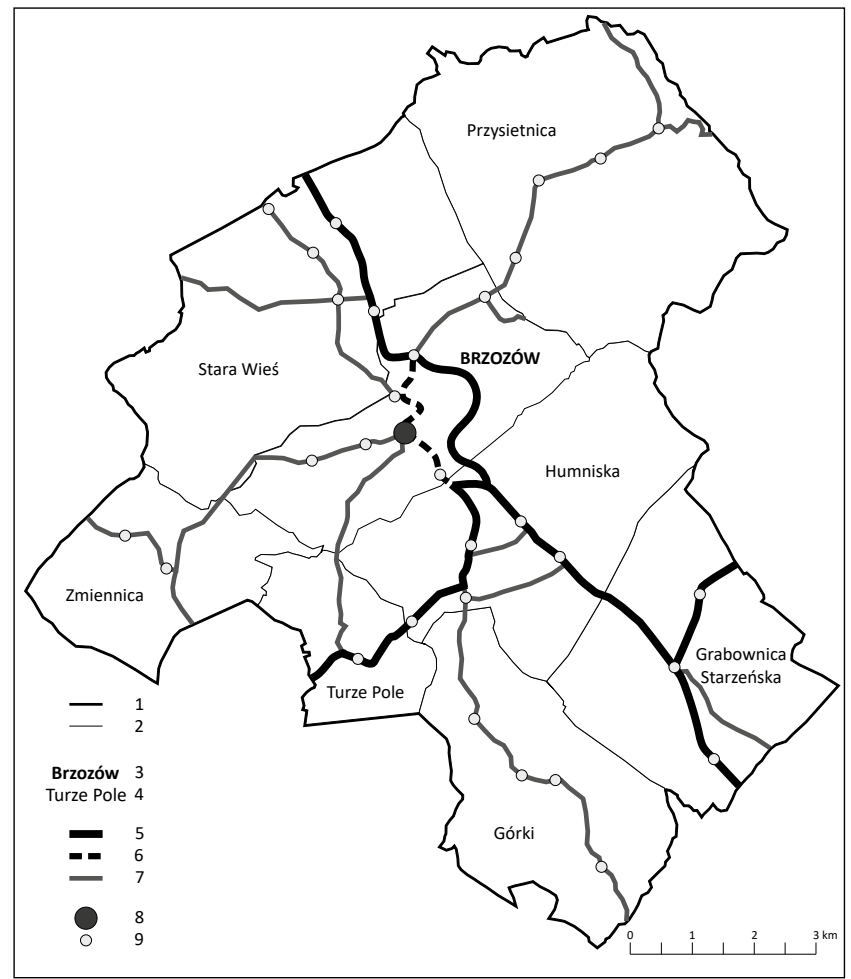

Figure 2. Administrative division and location of roads and bus stops in Brzozów municipality. Explanations: 1 - municipal boundary, 2 - town or village boundaries, 3 - town name, 4 - village name, 5 - provincial road, 6 - provincial road no. 886 before 19.11.2015, 7 - district road, 8 - bus station, 9 - bus stop

Source: author's own research.

of provincial roads in the Brzozów area has changed (Figure 2). There is no railway line running through the town.

\section{Research methods}

The research was based on the analysis of bus timetables and was supplemented by interviews with employees of transport companies. The starting point for the analyses was the acquisition of the timetables of the 16 carriers operating on permanent, year-round communication lines passing through the city. These data have been made available by the Town Hall in Brzozów, the District Office in Brzozów, and individual carriers. In the case of two communication lines, the timetables made available on the website www.autobusowykladjazdy.pl were used (this information was additionally confirmed by visiting selected bus stops in the field). Whether the timetables actually operated were verified during a field visit conducted on a weekday at six bus stops located in different parts of Brzozów. The actions carried out provided the basis for concluding that the data collected will allow one to obtain an image of the accessibility of public transport in the city that is both accurate and current. Nevertheless, obtaining timetables that reflect reality is not a simple task (Guzik et al. 2016). The problem of incomplete and outdated information is a problem that is not only associated with public transport in Poland. The availability of timetables constitutes one of the components of a properly functioning system (Cullinane \& Strokes 1998) and as a rule they should be made readily available (Veeckman et al. 2017). 
The data derived from timetables has been analysed according to the modified method described by R. Guzik (2010, 2012), in a database containing information on direct public transport connections (travel time and number of bus runs) between Brzozów and:

a) Rzeszów (the capital of Podkarpackie Province);

b) the capitals of the municipalities ${ }^{2}$ in Brzozów District (Domaradz, Dydnia, Haczów, Jasienica Rosielna, Nozdrzec);

c) capitals of districts surrounding Brzozów District (Krosno, Przemyśl, Rzeszów - previously included, Sanok, Strzyżów), attention: there is no direct connection with Przemyśl;

d) any city in Poland that is not mentioned above.

While creating the database, only buses running in one direction were taken into consideration (headed for a given location, for example, Rzeszów) .

Conducting the accessibility analysis requires, for instance, that one determine the points at which and to which such accessibility is examined (Guzik 2003). This is crucial in determining the travel time between the two locations. In the case of villages, this point was designated in the centre of the built-up area, on a topographical map at a scale 1:10 000, with consideration of the road network or the location of churches, schools, shops, etc. (Guzik 2003). In the case of cities, it was a bus station or other similar place.

Therefore, the factors that were taken into account are as follows: time (in minutes) needed to walk from the centre (village) to the bus stop, travel time, time needed to walk to the centre (village) and the total time. The time of walking between the centre and the bus stop was calculated assuming that the average person walks at a speed of $4 \mathrm{~km} / \mathrm{h}(1 \mathrm{~km} / 15 \mathrm{~min})$ (Guzik 2003). The time needed to get to/from the bus station was estimated at 5 minutes. The travel time was calculated as the average of all travel times for bus journeys reaching the location on a weekday between 6:00 a.m. and 7:59 a.m. and it was rounded to full minutes. If there was no bus reaching the given location within the hours specified above on the given bus route, the travel time of the first bus arriving after 8:00 a.m. was taken into account. Apart from the travel time, the number of buses arriving at the given location was determined:

a) on weekdays:

- 4:00 a.m. - 5:59 a.m.

- 6:00 a.m. - 7:59 a.m.

- 8:00 a.m. - 9:59 a.m.

b) outside the hours 4:00 a.m. - 9:59 a.m.

c) on Saturdays;

d) on Sundays.

A detailed analysis was only conducted for the morning traffic peak, as people's activity during these hours is connected with commuting to work, school and other places of similar importance (Guzik 2012). Therefore, it was considered that it was sufficient to restrict the analysis to buses departing from Brzozów alone - the arriving buses would represent the returns from the aforementioned locations. Another argument for the analysis of one-way bus trips is the design of timetables

Capital of municipality - the main town or village in the municipality where the municipal office is located which, in the vast majority of cases, takes a return bus run into account - hence the high probability of a similar number of buses going the other way (at similar hours). The analysis was conducted during the period of normal operation of public transport, not during holidays or non-working days, in the second half of January.

The data collected on the basis of the rules described above have made it possible to determine the locations that may be reached from Brzozów, their accessibility in terms of time and the frequency ${ }^{3}$ of buses departing to those places. In this paper, the term regularity was used, representing the reverse of frequency. It was understood as the intervals (expressed in minutes) between departures of public transport vehicles (Tracz 1984).

Detailed information on the motivation of carriers to create, change or remove bus routes could only be provided by the key decision makers or by authorised employees of transport companies. The source of such information was the set of interviews during which issues were discussed which related to the time and nature of activity on the passenger transport market, to changes that took place in companies' activities over time and space, as well as to their reasons. The interviews were conducted with the representatives of four companies varying in the type of bus or coach route, which they operate: 1) local 2) intercity and 3) long-distance. The first half of the research was based on live interviews, in the office of the carrier, and the second on phone calls. The respondents did not know the questions before the interview. They were asked about their length of presence on the market, the reasons for opening and closing bus routes, and reasons for changes in timetables. The carriers also provided information on future development plans.

\section{Existing public transport links}

\section{Links within the district}

The number of buses departing from Brzozów to the capitals of the four neighbouring communes on a weekday is rather low (Figure 3). This is particularly noticeable in the case of connec-

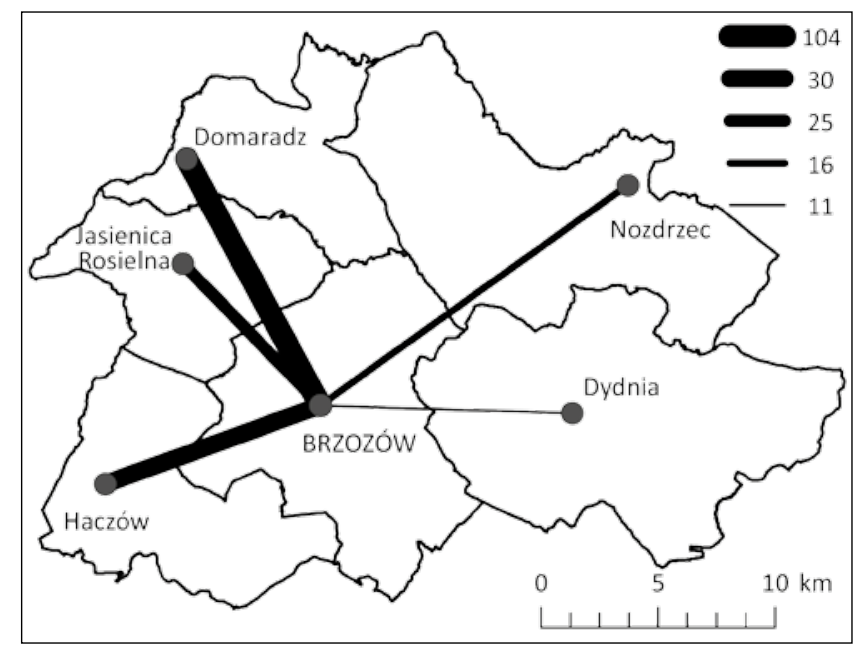

Figure 3. Number of trips from Brzozów to the capitals of municipalities in Brzozów District on weekdays.

Source: author's own research. 
tions with Nozdrzec and Dydnia - buses depart to these locations on average every hour (Nozdrzec) and every two hours (Dydnia) ${ }^{4}$. It is definitely easier to reach Jasienica Rosielna (every 46 minutes) and Haczów (every 38 minutes). The buses running from Brzozów to Domaradz operate on an extremely regular basis because they depart every 11 minutes. Such a strong connection between these two locations results directly from the very good bus route existing between Brzozów and Rzeszów, which is influenced by the road network in the area (Figure 2).

The accessibility of public transport in Brzozów District is clearly worse on Saturdays and Sundays (Figures 4-5). The demand for transportation during the weekend is obviously lower than on a weekday, but it is disturbing that there are no links to Jasienica Rosielna and Dydnia over the whole weekend or with Nozdrzec on Sundays. One should bear in mind that these are important locations having various functions on a local scale. The number of trips to Haczów also decreases significantly on Sundays (six times lower). On weekends, the high number of trips to Domaradz is maintained.

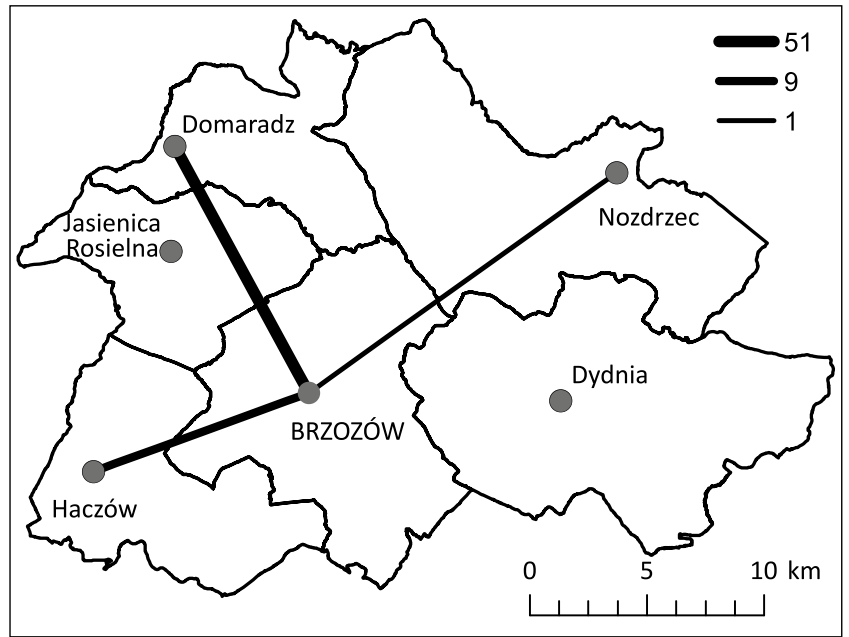

Figure 4. Number of trips from Brzozów to the capitals of municipalities in Brzozów District on Saturdays.

Source: author's own research.

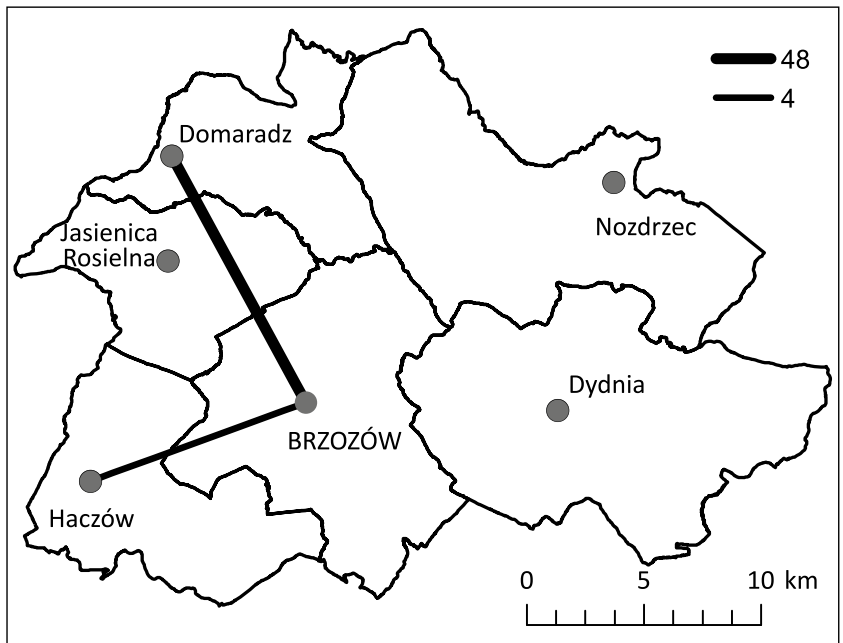

Figure 5. Number of trips from Brzozów to the capitals of municipalities in Brzozów District on Sundays.

Source: author's own research.

A period of 19 hours was counted as one day (1 140 minutes) from 04:00 a.m. to 23:00 p.m.

\section{Trips between districts}

The reform of Poland's administrative divisions in 1998-1999 resulted in a change in the importance and rank of cities (especially Krosno, Przemyśl and Rzeszów), therefore the connections that exist between Brzozów and those cities were analysed. The importance of the two capitals of districts that adjoin Brzozów District, Strzyżów and Sanok, was analysed. At this point, it should be explained that until 1999, Krosno was the capital of Krośnieńskie Province in which Brzozów was located.

It was noted above that there are no direct public transport links between Brzozów and Przemyśl. The situation is the same in the case of Strzyziow (Figures $6-8)$. However, it is possible to reach this city twice a day (on every day of the week). This connection is offered by one of the carriers operating on the Sanok - Brzozów Krakow route. It is a kind of response of a private company to the lack of a Strzyżów - Brzozów - Sanok railway line, the construction of which has been envisaged since the $19^{\text {th }}$ century (Marszałek Województwa Podkarpackiego 2014).

Much more interesting is the great accessibility of Sanok - buses run there every 10 minutes on weekdays, every

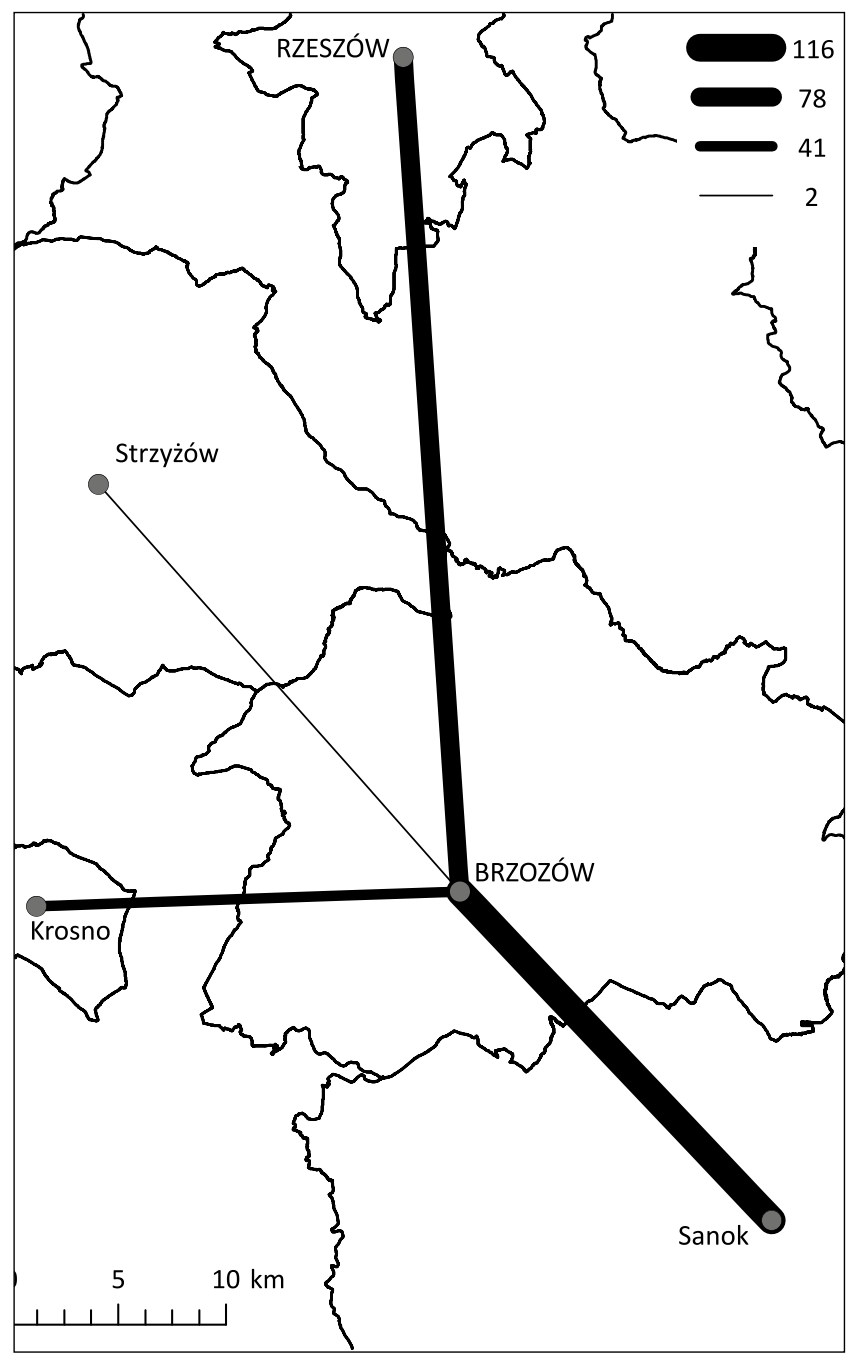

Figure 6. Number of trips from Brzozów to Rzeszów, Strzyżów, Krosno and Sanok on weekdays.

Source: author's own research. 


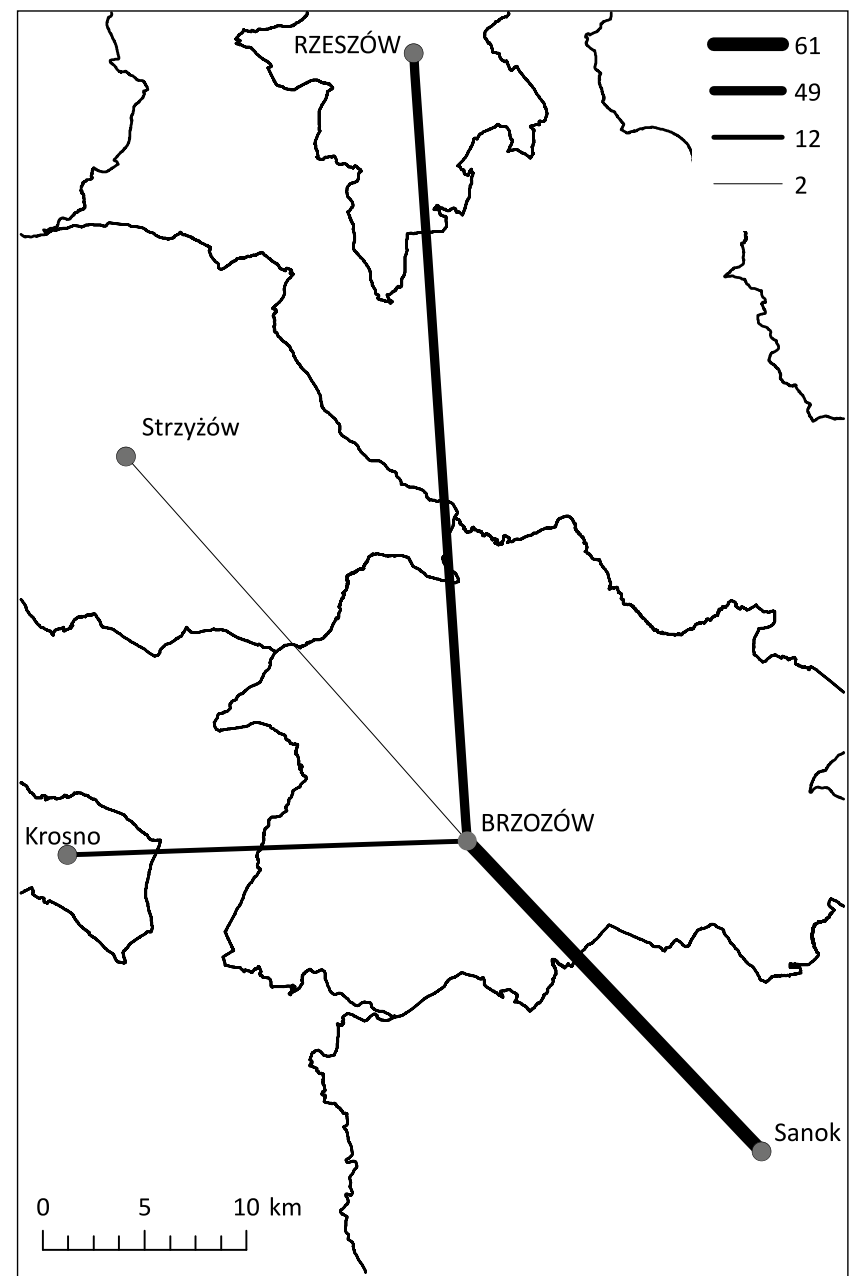

Figure 7. Number of trips from Brzozów to Rzeszów, Strzyżów, Krosno and Sanok on Saturdays.

Source: author's own research.

19 minutes on Saturdays and every 22 minutes on Sundays. This is due to the existence of many bus companies operating buses along two routes:

- the shorter one through Humniska and Grabownica Starzeńska (route: Rzeszów - Sanok)

- the longer one through Humniska and Turze Pole (routes: Brzozów - Krosno, local route Turze Pole - Zarszyn and Krosno - Sanok).

The issue of accessibility to Rzeszów - the capital of the region - was examined in a more detailed manner and the analyses not only took the number of trips and the frequency of bus operation resulting from it into account but, according to R. Guzik (2012), also the travel time (Tables 1-3). The best possible travel time to Rzeszów was estimated at 60 minutes for the bus journey plus 10 minutes for the walk, which gave a total of 70 minutes. The following accessibility ratings were determined by increasing this time by intervals of 30 minutes. The basis for the assessment of the number of trips to Rzeszów was the frequency of bus operation in different traffic conditions, where the basis for the lowest convenience class was a lack of connections, and the existence of at least one trip was the second most important factor. On a weekday, a 15-minute frequency was adopted as ideal. In the case of further

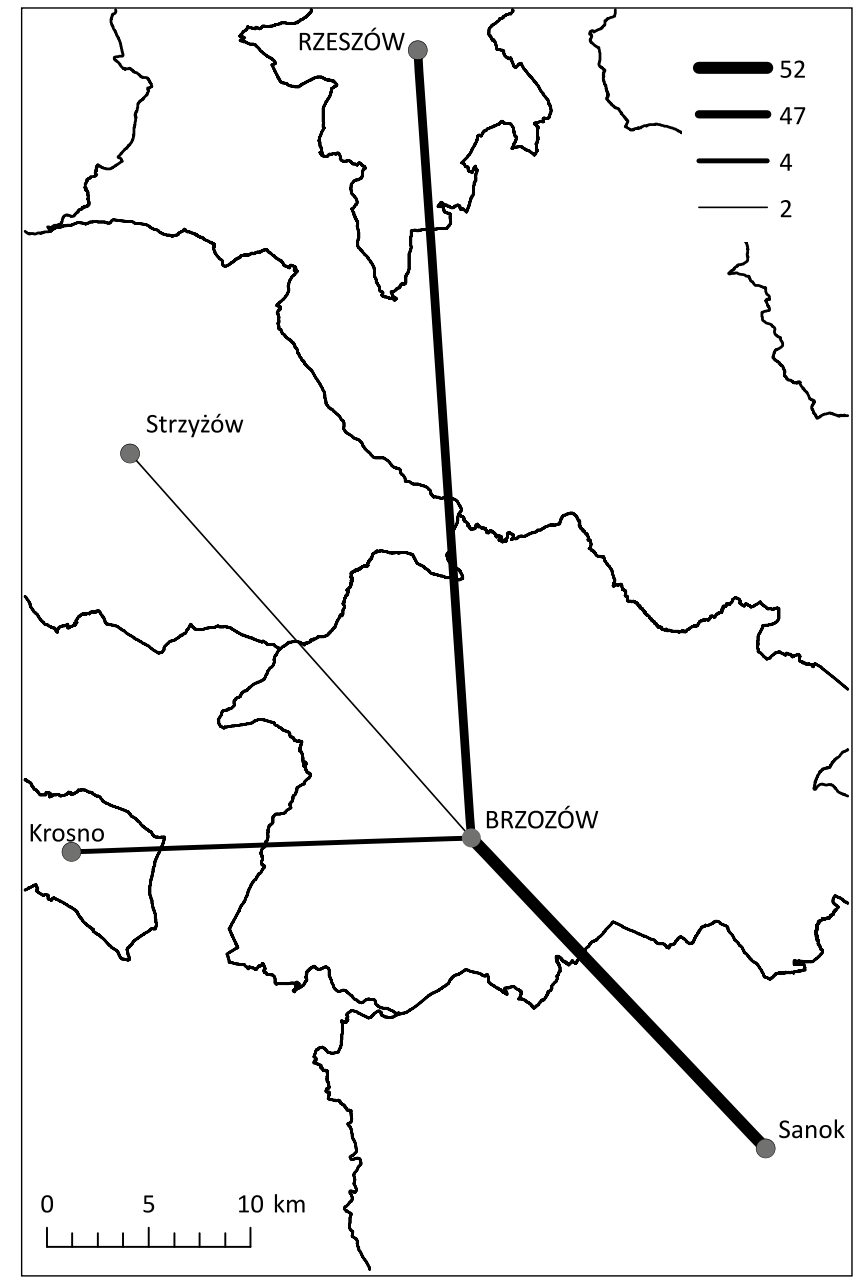

Figure 8. Number of trips from Brzozów to Rzeszów, Strzyżów, Krosno and Sanok on Sundays.

Source: author's own research.

accessibility ratings this time was doubled and when analysing traffic in the morning traffic peak it was increased by intervals of 15 minutes. In the case of weekends, the criteria were slightly modified (Table 3). According to the criteria listed above, the accessibility of Rzeszów using public transport from Brzozów can be assessed as almost ideal. This applies both to weekdays and weekends. This convenience classification falls to a very good level for connections in the morning traffic peak on weekdays. It should be noted that these criteria are very demanding which confirms the importance of the Brzozów-Rzeszów route and the existence of strong functional links between these cities.

As Krosno was the capital of the province until relatively recently, the decision was made to verify to what extent Brzozów is connected with Krosno - whether or not there are still strong spatial links. For this purpose, as in the case of Rzeszów, a similar accessibility rating tool was applied. However, the criteria for travel time were different due to the fact that the distance between these towns is shorter (ideal travel time: 30 minutes, further classes increase at intervals of 15 minutes). It turns out that the rating of accessibility of Krosno from Brzozów is very good on weekdays, good on Saturdays and poor on 
Table 1. Evaluation of accessibility of Rzeszów via public transport on weekdays.

\begin{tabular}{|c|c|c|c|c|c|c|c|c|}
\hline & \multicolumn{6}{|c|}{ total travel and walking time in minutes } & \multirow{2}{*}{$\begin{array}{l}\text { regularity } \\
\text { of operation }\end{array}$} \\
\hline & & $<71$ & $71-100$ & $101-130$ & $131-160$ & $161-190$ & $>190$ & \\
\hline \multirow{6}{*}{ 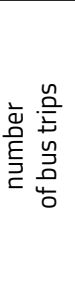 } & $>75$ & & BRZOZÓW & & & & & every 15 min. \\
\hline & $38-75$ & & & & & & & every 30 min. \\
\hline & $19-37$ & & & & & & & every 60 min. \\
\hline & $10-18$ & & & & & & & every $120 \mathrm{~min}$. \\
\hline & $1-9$ & & & & & & & \\
\hline & 0 & & & & & & & \\
\hline
\end{tabular}

Source: author's own research.

Table 2. Evaluation of the accessibility of Rzeszów via public transport on weekdays between 4:00 a.m. and 9:59 a.m.

\begin{tabular}{|c|c|c|c|c|c|c|c|c|}
\hline & & \multicolumn{6}{|c|}{ total travel and walking time in minutes } & \multirow{2}{*}{$\begin{array}{l}\text { regularity } \\
\text { of operation }\end{array}$} \\
\hline & & $<71$ & $71-100$ & $101-130$ & $131-160$ & $161-190$ & $>190$ & \\
\hline \multirow{6}{*}{ 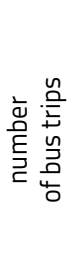 } & $>23$ & & & & & & & every $15 \mathrm{~min}$. \\
\hline & $12-23$ & & BRZOZÓW & & & & & every $30 \mathrm{~min}$. \\
\hline & $8-11$ & & & & & & & every $45 \mathrm{~min}$. \\
\hline & $6-7$ & & & & & & & every $60 \mathrm{~min}$. \\
\hline & $1-5$ & & & & & & & \\
\hline & 0 & & & & & & & \\
\hline
\end{tabular}

Source: author's own research.

Table 3. Evaluation of the accessibility of Rzeszów via public transport on weekends.

\begin{tabular}{|c|c|c|c|c|c|c|c|c|}
\hline & & \multicolumn{6}{|c|}{ total travel and walking time in minutes } & \multirow{2}{*}{$\begin{array}{l}\text { regularity } \\
\text { of operation }\end{array}$} \\
\hline & & $<71$ & $71-100$ & $101-130$ & $131-160$ & $161-190$ & $>190$ & \\
\hline \multirow{6}{*}{ 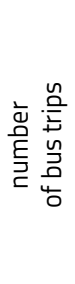 } & $>37$ & & BRZOZÓW & & & & & every $30 \mathrm{~min}$. \\
\hline & $19-37$ & & & & & & & every $60 \mathrm{~min}$. \\
\hline & $10-18$ & & & & & & & every $120 \mathrm{~min}$. \\
\hline & $6-9$ & & & & & & & every $180 \mathrm{~min}$. \\
\hline & $1-5$ & & & & & & & \\
\hline & 0 & & & & & & & \\
\hline
\end{tabular}

Source: author's own work.

Note to tables: scale of accessibility ratings: ideal, very good, good, poor, very poor, none.

Sundays. In view of the above, it can be concluded that the links between Brzozów and Krosno are significantly weaker than between Brzozów and Rzeszów. In the case of Krosno, commuting to work is evident - the number of trips on Sundays is small.

\section{Long-distance connections}

Apart from the cities mentioned above, it is also possible to use public transport to reach other cities in Poland. The connections from Brzozów can be divided into four groups:

- to Wrocław through Krakow and Krosno or Rzeszów, Dębica and Tarnów;

- to Warsaw through Radom;
- $\quad$ to Lublin through Janów Lubelski and Nisko;

- to Ustrzyki Dolne through Lesko and Zagórz.

In general, it is possible to reach the main Polish cities from Brzozów, especially those located in southern, eastern and central Poland (Figures 9-10). This phenomenon should be associated with the academic function of these cities. This relationship is also confirmed by the weekly timetables. The number of long-distance connections does not decrease over the weekend as clearly as in the case of local connections. This is linked with, among other factors, those undertaking full-time and weekend studies, as well as tourism. One can distinguish the trips heading for the tourist region of the Bieszczady Mountains among the network of connections. 


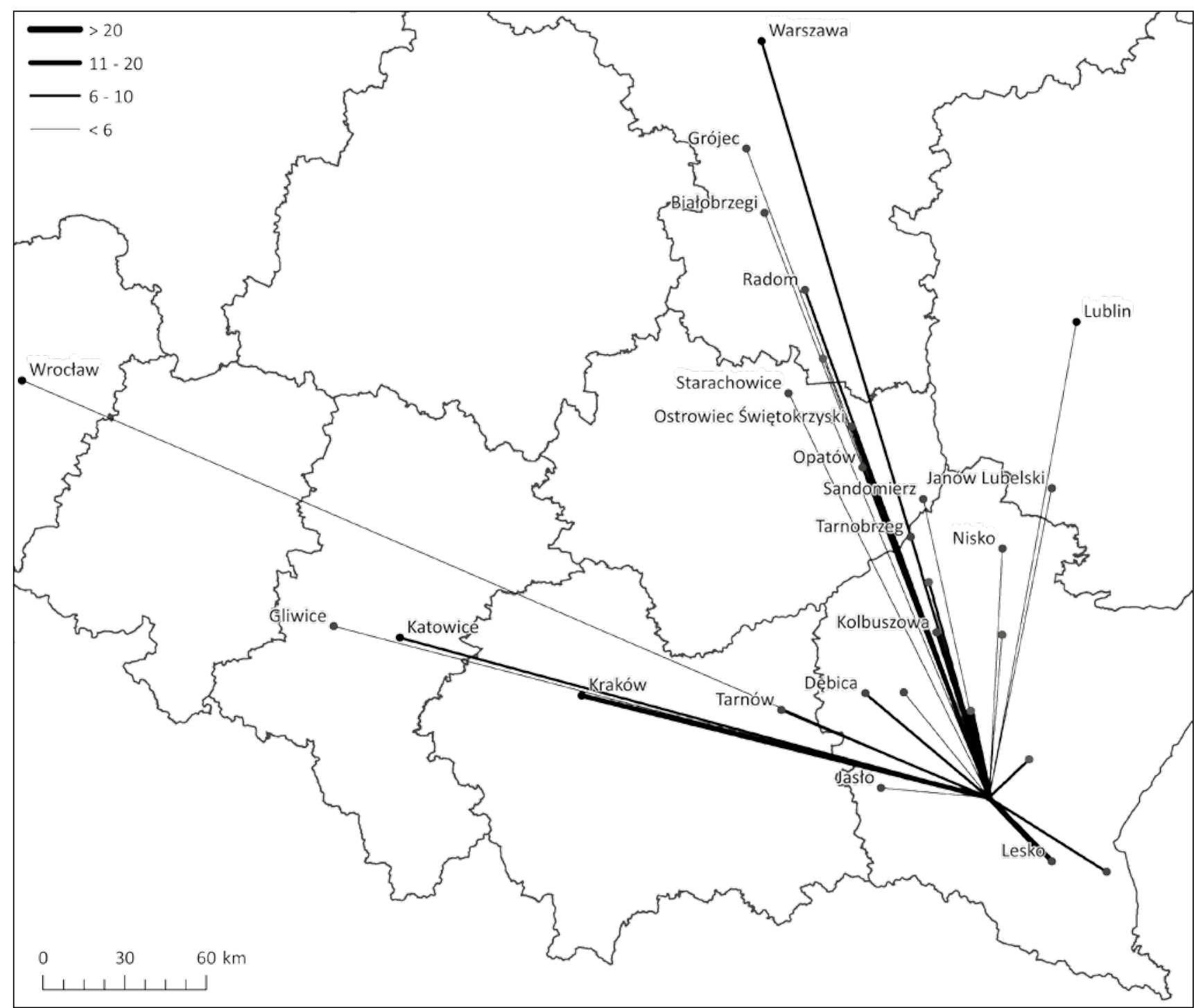

Figure 9. Number of connections from Brzozów to cities in Poland located outside of Brzozów District (without Rzeszów, Strzyżów, Krosno and Sanok) on weekdays.

Source: author's own research.

\section{Accessibility by public transport in Brzozów}

Within the territory of Brzozów there is no municipal public transport system. Access to public transport is provided by the local, intercity and long-distance bus companies. A small town like Brzozów needs strong connections with neighbouring larger cities - for both economic and social reasons. Therefore, the existence of public transport connections is crucial.

An important factor that shapes the public transport system in Brzozów - apart from its location in the settlement network - is the location of the city on a very important route in this part of the region which connects Rzeszów with Sanok and the region of the Bieszczady Mountains. The best proof of this is seen in the 170 pairs of bus links running through the city centre (using the former provincial road - now the local road).

At the local scale, Domaradz and Haczów are the locations that are the most accessible from Brzozów. On a wider scale, it is Rzeszów, Sanok and Krosno. While discussing connections with cities across the country, the four locations having strong links should be emphasised: Ustrzyki Dolne, Krakow, Warsaw and Lublin.

As far as accessibility is concerned, there is a big disproportion between the western and the eastern part of Brzozów District. Poor connections may require improvement, but this is unlikely without any public support. When it comes to the rest of the country, there are no connections with the northern part of Poland, however it should be noted that only year-round routes were included in the research. There are, nevertheless, seasonal connections between northern and south-eastern Poland.

According to passengers, the key changes in the functioning of the communication network are: the launching of new bus routes, the reorganisation of existing routes, and their removal. The carriers indicated the profound changes in the functioning of PKS Krosno S.A. as the main reason for launching the new routes. This company was until recently the major carrier (2012-2013), a monopoly on the local and intercity markets, and it played a sig- 


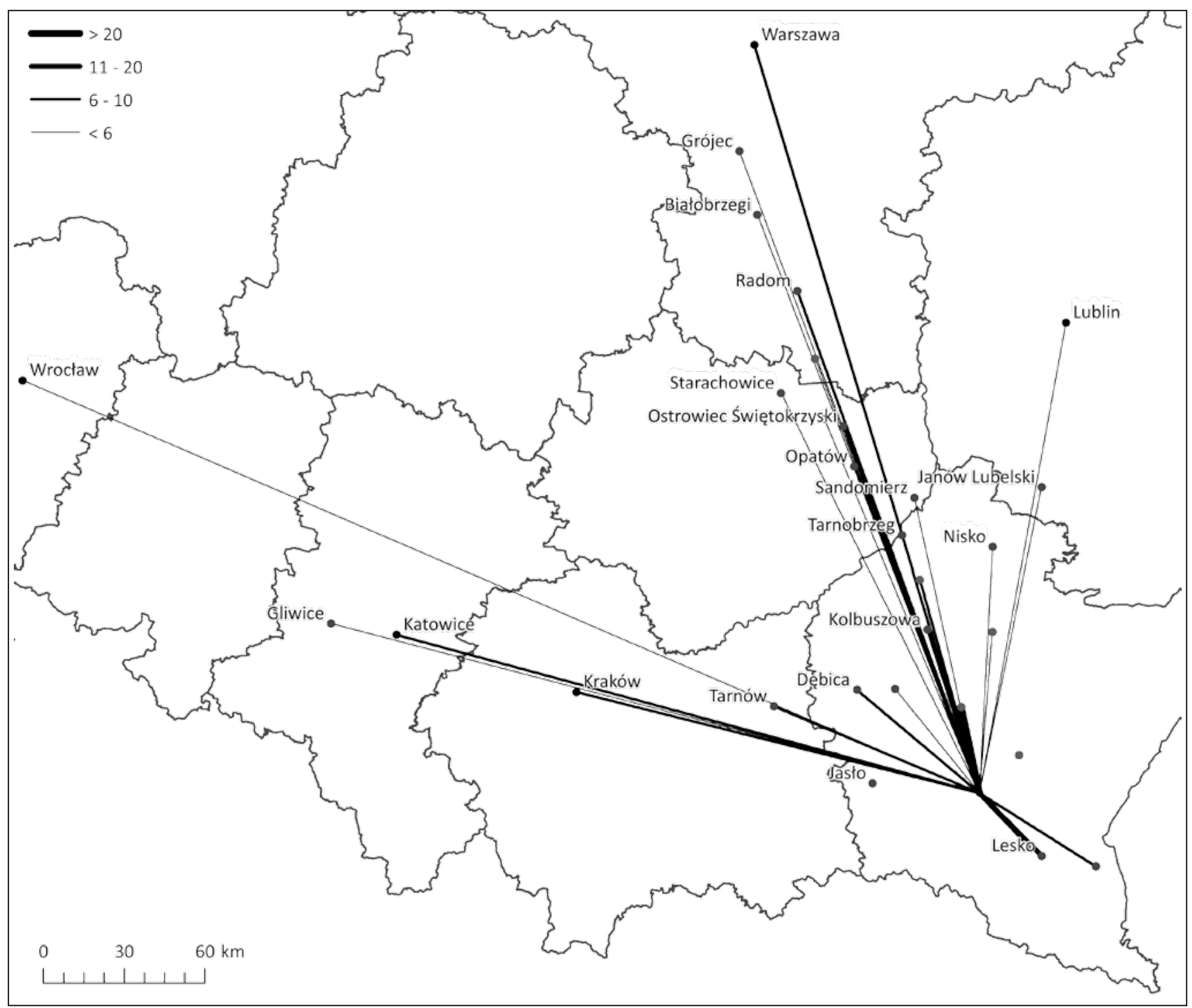

Figure 10. Number of connections from Brzozów to cities in Poland located outside of Brzozów District (without Rzeszów, Strzyżów, Krosno and Sanok) on Saturdays and Sundays.

Source: author's own research.

nificant role in the field of long-distance transport services. Nevertheless, after the organisational changes and subsequent privatisation, most of the bus routes were removed and services were often delivered without respecting the timetables. Smaller companies that had been delivering their services on single routes quickly attempted to fill this gap. The demand for transport services was, and still is, very high, which is confirmed by the carriers who claim that passengers request the opening of new routes and bus services at new times.

The second major carrier, both on the local, intercity and long-distance transport market, was ARRIVA Sp. o.o. (formerly Veolia Transport, PKS Connex), the privatised former state-owned Motor Transport Company (PKS) in Brzozów. During interviews, the smaller carriers indicated that competing with this company was one of their aims. They did it by improving their service in terms of vehicles, prices or changes in the timetables. In February 2017 ARRIVA Sp. z o.o. announced the closing of its branches in Brzozów, Sanok and Ustrzyki Dolne (Fiszer 2017). Their buses ceased operating their services on June 30, 2017. This will be another critical juncture for public transport in Brzozów region.

A special role in the public transport system is played by the so-called "school runs" that ensure the transport of students to and from schools, mostly high schools located in the major cities of the region: Krosno, Sanok or Brzozów. The need to transport students is often a reason for launching new bus routes or bus services at new times on the routes that already exist.

Another very important group, the needs of which determine the timetables in the communication network, consists of those who commute to workplaces located in major cities. The three-shift system of working applied in the biggest companies which have a large number of employees and the hours when these shifts start: 6:00 a.m., 14:00 p.m. and 22:00 p.m. have a significant influence on the design of such timetables.

As far as long-distance bus services are concerned, carriers claim that the main group of passengers constitute students. Therefore, the role of communication links with the main 
academic cities in the country is crucial. This mainly refers to Krakow, but also to Lublin, Warsaw and Wrocław. The carriers, while developing their offer within the study area of the research, seek to create a system allowing passengers to reach a destination point in one or several selected locations with only one change en route. Such action is designed to increase the accessibility of academic cities while at the same time reducing the operational costs for the company.

Generally, the carriers are not willing to remove routes which they operate. Interestingly, the concluding of informal agreements between transport companies operating on certain routes is quite a common practice. If their business is not profitable, only one company remains on the market due to such "agreements". Such actions were confirmed in several conversations so they are not individual or isolated incidents. Another problem that forces carriers to remove routes are problems associated with obtaining the official administrative permissions to use bus stops.

Changes in the current range of transport services on offer are usually a response of carriers to the measures undertaken by their competition. Such events ultimately lead to the improvement of the communication services to particular locations by a reduction in prices, improvement of vehicle quality and increase in the number of bus services on particular routes.

The need to adapt to certain solutions and formal requirements is important in addition to the changes dictated by the transport needs of the inhabitants of certain locations. The main problem is access to the bus station in Brzozów. Due to the fact that this area is managed by a private company that prohibits vehicles of other companies from entering the bus station, the vast majority of departures from the city centre take place from one bus stop. It is located near the bus station, but its size and the lack of the possibility of any change hinder its use which affects both carriers and passengers. The bus bay is small so only one bus may use it at any one time. For this reason, the owner of the bus stop significantly limits the frequency of departures so that the traffic flows smoothly. These limits often cause changes to the carriers' timetables. As a result, their offers become less attractive. Another problem is the lack of official administrative control over the degree to which the carriers respect the timetables, which often leads to abuses and has a negative influence on the competition that is so desirable in a market economy.

\section{Discussion and conclusions}

In urban areas in both Poland and Europe, in a similar manner to the situation in American cities, a natural relationship has been observed between the development of the road network and the population density in the area (Garcia-López 2012). Equally important is the fact that the transport system always functions in a regional context and the relationship between the structure of the region and transport is bilateral (Haag \& Grützmann 2001). Brzozów is a perfect example that confirms the theories mentioned above. The location of the city on an important road (Rzeszów - Sanok) significantly influences transport accessibility, including public transport. The network of routes is mainly based on this road, which can be called the transport axis of the Brzozów region.
It undoubtedly affects the functioning of the city in the economic and social sphere. There is a strong interaction between the transport system (including public transport) and regional development (Haag \& Grützmann 2001). Public transport, which is an alternative to and substitute for individual transport, constitutes one of the tools that is used to combat transport exclusion (Iles 2005).

The desire to adapt the transporters' services to the needs of students and the employees of large companies on the local market as well as to the needs of university students on the market of long-distance transport was indicated as the main reason for changes in the public transport system in the study area. The relatively small transport companies also compete with each other, trying to reduce or even marginalise the activities of large motor transport companies. These are the characteristic features of a transport system after the limitations that an ineffective public carrier has introduced into its activity (Iles 2005).

The functioning of the public transport system within the territory of the municipality is satisfactory on weekdays, but requires improvement, especially on Sundays. A development that would definitely improve the functioning of the system under examination within the territory of the municipality would be the creation of a publicly accessible bus station in Brzozów, which would serve as a transport hub. Another important issue that requires improvement is the legal system that hinders the smooth operation of the system (Iles 2005).

There are certain tools that are recommended in order to improve public transport in rural areas (such as Brzozów): the creation of a passenger information system, not only at bus stops (e.g. in large stores or restaurants), the construction of Park and Ride car parks permitting the introduction of changes in public transport, and improving the ticket purchase process (ticket integration) (Cullinane \& Strokes 1998). The lack of the possibility of buying one ticket permitting the use the services of different carriers in the Brzozów region has a negative impact on the quality of public transport.

In conclusion, the accessibility of public transport in Brzozów is quite good and requires relatively few changes in order to be considered optimal. Recent changes on the local passenger transport market have brought very positive results and plans for the future are very promising.

Being a peripheral location in the settlement hierarchy, Brzozów does not fully meet the needs of the inhabitants of the region to which it belongs. Therefore, high external accessibility of this town gives it a chance to develop, both in the economic and social contexts. Brzozów is a town that has very good communications with locations of similar rank and above all with the main cities in the region and country. As pointed out by M. Dej (2010), in similar areas of Poland public transport often does not meet the communication needs of the residents, even the most basic ones - such as the need to commute to work. Therefore, Brzozów is an exception. Despite its peripheral economic importance, it is located in a certain kind of core when it comes to the issue of transport. Due to its high transport accessibility, the life opportunities of the population increase (Pacione 1989) which significantly decreases social exclusion (Cass et al. 2005, Farrington 2007). Location in the vicinity of important regional and national roads has a positive 
impact on the accessibility of public transport, as evidenced by research carried out in the Czech Republic (Ivan et al. 2013). Moreover, the economic potential of Brzozów may be enhanced by improving the quality of human and social capital, both on a local and regional scale. Such good opportunities for eco- nomic development closely correlated with the functioning of the transport system are not common in cities of a rank that is lower than regional, and strengthening relations in the region is an important factor stimulating social and economic growth (Garmendia, de Ureña, Ribalaygua, Leal \& Coronado 2008).

\section{References}

Black, J. \& Conroy, M. (1977) Accessibility Measures and the Social Evaluation of Urban Structure, Environment and Planning A, 9, 1013-1031.

Cass, N., Shove, E. \& Urry, J. (2005) Social exclusion, mobility and access, Sociological Review, 53, 539-555.

Cullinane, S. \& Strokes, G. (1998) Rural Transport Policy, Pergamon, Amsterdam-Lausanne-New York-Oxford-Shannon-Singapore-Tokyo.

Dej, M. (2010) Transport publiczny w wiejskich obszarach peryferyjnych Polski i jego dostosowanie do potrzeb lokalnych rynków pracy, Prace Geograficzne, 124, 111-130 [in Polish with English summary].

Farrington, J. (2007) The new narrative of accessibility. Its potential contribution to discourses in (transport) geography, Journal of Transport Geography, 15, 319-330.

Garcia-López, M. A. (2012) Urban spatial structure, suburbanization and transportation in Barcelona, Journal of Urban Economics, 72, 176-190.

Garmendia, M., de Ureña, J. M., Ribalaygua, C., Leal, J. \& Coronado, J. M. (2008) Urban residential development in isolated small cities that are partially integrated in metropolitan areas by high speed train, European Urban and Regional Studies, 15, 249-264

Guzik, R. (2003) Przestrzenna dostępność szkolnictwa ponadpodstawowego, IGiGP UJ, Kraków.

Guzik, R., Zborowski, A., Kołoś, A., Micek, G., Gwosdz, K., Trzepacz, P., Chaberko, T., Kretowicz, P., Ciechowski, M., Dej, M. \& Grad, N. (2010) Dostępność komunikacyjna i powiq̨ania miast oraz delimitacja obszarów funkcjonalnych [in:] B. Domański \& A. Noworól, eds., Małopolskie miasta - funkcje, potencjat i trendy rozwojowe, Departament Polityki Regionalnej Urzędu Marszałkowskiego Województwa Małopolskiego, Kraków, 88-134 [in Polish].

Guzik, R., ed. (2012) Czynniki i ograniczenia rozwoju miast województwa pomorskiego $w$ świetle relacji przestrzennych i dostępności komunikacyjnej, Urząd Marszałkowski Województwa Pomorskiego, Gdańsk [in Polish].

Guzik, R., Kołoś, A., Gwosdz, K., Biernacki W., Działek J., Kocaj A., Panecka-Niepsuj, M. \& Wiedermann, K. (2016) Dostępność, relacje i powiazania przestrzenne w Miejskim Obszarze Funkcjonalnym Olsztyna, IGiGP UJ, Kraków.

Haag, G. \& Grützmann, K. (2001) Transport and Urban Development [in:] G. Clarke \& M. Madden, eds., Regional Science in Business, Springer, Berlin-Heidelberg, 189-210.

Iles, R. (2005) Public Transport in Developing Countries, Elsevier, Amsterdam-Boston-Heidelberg-London-New York-Oxford-Paris-San DiegoSan Francisco-Singapore-Sydney-Tokyo.

Ivan, I., Horak, J., Fojtik, D. \& Inspektor, T. (2013) Evaluation of public transport accessibility at municipality level in the Czech Republic, Inter- national Multidisciplinary Scientific GeoConference: SGEM: Surveying Geology \& mining Ecology Management, Sofia, Surveying Geology \& Mining Ecology Management (SGEM), 527-534.

Komornicki, T., Śleszyński, P., Rosik, P. \& Pomianowski, W. (2009) Dostępność przestrzenna jako przesłanka ksztaltowania polskiejpolityki transportowej (Biuletyn KPZK PAN, 240) [in Polish with English abstract].

Marszałek Województwa Podkarpackiego (2014) Plan zrównoważonego rozwoju publicznego transportu zbiorowego dla Województwa Podkarpackiego, zał. Do Uchwały nr LIV Sejmiku Województwa Podkarpackiego z dnia 22.04.2014 r. [in Polish].

Moseley, M. J. (1979) Accessibility: The Rural Challenge, London, Methuen. Paccione, M. (1989) Access to urban services. The case of secondary schools in Glasgow, Scottish Geographical Magazine, 105, 12-18.

Ratajczak, W. (1992) Dostępność komunikacyjna miast wojewódzkich Polski w latach 1948-1988 [in:] Z. Chojnicki \& T. Czyż, eds., Wspótczesne problemy geografi społeczno-ekonomicznej Polski (Seria Geografia UAM w Poznaniu, 55), 173-203 [in Polish].

Taylor, Z. (1997) Dostępność miejsc pracy, nauki i uslug w obszarach wiejskich jako przedmiot badań geografi społeczno-ekonomicznej - próba analizy krytycznej, Przegląd Geograficzny, 69 (3-4) 261-283 [in Polish].

Taylor, Z. (1999) Przestrzenna dostępność miejsc zatrudnienia, kształcenia i usług a codzienna ruchliwość ludności wiejskiej (Prace Geograficzne 171), IGiPZ PAN, Wrocław [in Polish with English summary].

Ustawa $z$ dnia 16 grudnia 2010 r. o publicznym transporcie zbiorowym, t.j. DzU 2015 r. poz. 1440, 1753, 1890, 1893 [in Polish].

Tracz, M. (1984) Badania ruchu komunikacji zbiorowej [in:] M. Tracz, ed., Pomiary i badania ruchu drogowego, Wydawnictwa Komunikacji i Łączności, Warszawa, 83-88.

Veeckman, C., Jedlička, K., De Paepe, D., Kozhukh, D., Kafka, S., Colpaert, P. \& Čerba, O. (2017), Geodata interoperability and harmonization in transport a case study of open transport net, Open Geospatial Data, Software and Standards, 2 (1): 3.

Warakomska, K. (1992) Zagadnienie dostępności w geografii transportu, Przegląd Geograficzny, 64 (1-2), 67-76 [in Polish with English abstract].

\section{Internet sources}

Cambridge Dictionary, Public transport, http://dictionary.cambridge.org/ dictionary/english/public-transport [accessed: 30.04 .2017 ]

Fiszer K., 17.02.2017, Arriva wycofuje się z Podkarpacia, Transport Publiczny. Available from: http://www.transport-publiczny.pl/wiadomosci/arrivawycofuje-sie-z-podkarpacia-54336.html [accessed: 30.04.2017] [in Polish]. Główny Urząd Statystyczny, Bank Danych Lokalnych, https://bdl.stat.gov. pl/BDL/start [accessed: 30.04.2017] [in Polish]. 